\title{
АВТОМАТИЗАЦІЯ ПРОЦЕСУ ОБІГРІВАННЯ ПІДЛОГИ З ВИКОРИСТАННЯМ ТЕПЛОВОГО НАСОСУ
}

Automation of floor heating process with heat pump using

Сиротюк I.B. (Syrotyuk I.V.)

${ }^{1}$ Одеська національна академія харчових технологій, м.Одеса

${ }^{1}$ E-mail: ilyxin_09@mail.ru

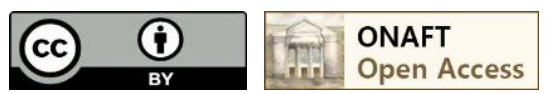

DOI: $10.15673 /$

\begin{abstract}
Анотація
Розглянуто спосіб обігрівання підлоги з використанням теплового насосу. Були отримані передатні функції каналів об'скту управління та побудовано базову структуру САР з ПІД-регуляторами в кожному каналі. Запропоновано реалізацію САР підвищеної динамічної точності, а саме каскадної у контурі регулювання температури перегріву холодоагенту у випарнику теплового насосу, проміжною точкою якої с поточне значення тиску холодоагенту у випарнику теплового насосу. Вимірювання та підтримання тиску
\end{abstract}

холодоагенту у випарнику теплового насосу с необхідним через достатньо велику інерційність температури перегріву холодоагенту, що призводить до різкого зниження динамічної точності САР. Було розроблено ескізи проектної документації зі схемами автоматизації, підключень та живлення для контролерів двох різних фірм: Fastwell та SIEMENS. Також була передбачена розробка ескізів проектної документації монтажної схеми щита керування для оператора-технолога на базі контролера фірми SIEMENS. Для випадку, коли присутня можливість використання сенсорної панелі для АРМ оператора-технолога була забезпечена програмна реалізація дистанційного керування процесом обігрівання підлоги у вигляді SCADAсистеми з використанням середовища програмування контролерів Siemens Simatic Step7 та середовища для створення людино-машинного інтерфейсу Simatic WinCC Flexible для контролерів сімейства Simatic S7-300, що передбачає набагато більше можливостей для оператора-технолога у ході керування процесом. Подібне АРМ було розроблене і для контролерів сімейства Fastwell IO з використанням середовища програмування контролерів CoDeSys, яка в свою чергу передбачає у собі і програмну реалізацію дистанційного керування процесом, і реалізацію людино-машинного інтерфейсу.

\section{Abstract}

The floor heating method with heat pump using was considered. Transfer functions of control object were received and base structure of ASC with PID-regulators in each channel was built. Realization of higher dynamic efficiency ASC, such as cascade in regulating contour of refrigerant superheat temperature in the heat pump evaporator, where intermediate point is the present value of refrigerant pressure in the heat pump evaporator. Measurement and maintaining of refrigerant pressure in the heat pump evaporator are necessary because of big enough inertia of refrigerant superheat temperature, which causes a sharp decrease of dynamic efficiency of ASC. Project documentation sketches of automation, connections and power schemes for controllers of two different firms: Fastwell and SIEMENS was developed. Also development of project documentation sketches of wiring diagram control shield for operator-technologist on SIEMENS controller was provided. For the case, when ability of sensor panel using for operator-technologist AWP is present the program realization of floor heating process distance control was provided in the form of SCADA-system with using of controller programming environment Siemens Simatic Step7 and environment for human-machine interface creating Simatic WinCC Flexible for family controllers Simatic S7-300, it provides more possibilities for operator-technologist during process control. The similar AWP was provided for family controllers Fastwell IO with controller programming environment CoDeSys 
using, which provides both program realization of process distance control and human-machine interface realization.

Ключові слова

Управління, тепла підлога, тепловий насос, АРМ оператора-технолога.

Сьогодення оточує нас бурхливим розвитком технологій та стрімким зростанням їх чисельності навіть у попиті. Але разом із цим непомірно збільшується споживання енергоресурсів на їх роботу та обслуговування, що призводить до різкого зменшення їх запасу i, відповідно, значного підвищення ціни відповідних ресурсів. Особливо це стосується опалення, забезпечення якого є одним із найбільш енергоємних процесів і потребує значних грошових витрат. Для вирішення цієї проблеми були розроблені різноманітні технології опалення, які підтримують необхідні умови мікроклімату при мінімальному споживанні енергоресурсів. Однією із найбільш ефективних технологій опалення є система обігрівання підлоги, що отримала назву «тепла підлога».

Система «тепла підлога» бурхливо розвивається в останні роки. Опалення підлогою найкращим чином відповідає вимогам до сучасних систем опалення. Для підігріву циркулюючої по трубам води або іншого теплоносія можна використовувати різні джерела енергії: тепло навколишнього середовища, деревину, газ, електрику або сонячну енергію. Опалення підлоги $\epsilon$ низькотемпературною системою опалення, внаслідок великих поверхонь нагріву температура теплоносія має лише ненабагато перевищувати температуру в приміщенні.

При використанні теплої підлоги в якості джерела енергії використовують низько потенціальне тепло навколишнього середовища 3 використанням теплового насосу (ТН). Тепловий насос найбільш ефективний в системі опалення підлоги, оскільки така система опалення використовує низькотемпературний теплоносій. Чим менше різниця між температурою джерела тепла (свердловини, наприклад) і температурою поданого в систему опалення теплоносія, тим більше коефіцієнт ефективності теплового насосу.

Для забезпечення більш ефективної роботи даної системи необхідно забезпечити автоматичне управління ТН. Відомі різноманітні способи управління ТН. Зокрема існує спосіб автоматичного управління процесом обігрівання підлоги 3 використанням теплового насосу, в якому підтримують задане значення температури на виході системи обігрівання підлоги зміною частоти обертів приводу компресора та температури холодоагенту на виході 3 випарника теплового насосу зміною положення регулюючого клапану подачі холодоагенту [1]. Недоліком даного способу є недосконалість системи управління через відсутність вимірювання та підтримки тиску у випарнику теплового насосу, що призводить до можливих порушень нормальної роботи теплового насосу. Також висока інерційність змінення температури при зміненні витрат холодоагенту призводить до низької динамічної точності управління. На кафедрі автоматизації технологічних процесів та робототехнічних систем ОНАХТ був запропонований спосіб управління ТН, в якому вимірюється та підтримується тиск холодоагенту у випарнику теплового насосу, який являє собою проміжну точку в контурі регулювання температури перегріву холодоагенту у випарнику ТН, таким чином підвищуючи динамічну точність іiі регулювання. Згідно цьому була побудована каскадна САР.

На рисунку 1 зображена технологічна схема системи обігрівання підлоги з використанням теплового насосу згідно описаного способу.

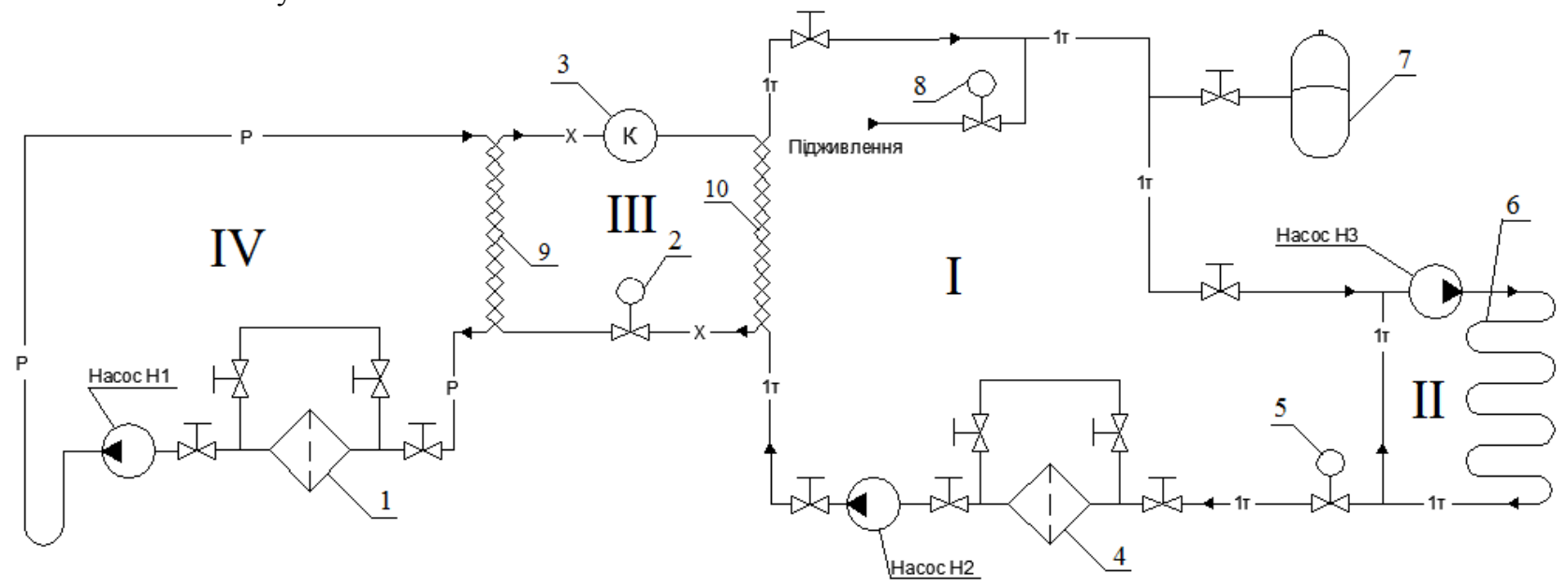

Рис. 1 - Технологічна схема системи обігрівання підлоги з використанням теплового насосу 


\section{СТУДЕНТСЬКА НАУКА}

Система складається 3 чотирьох контурів. Головний контур (I) має підживлення із зовнішньої мережі водопостачання, яке здійснюється шляхом відкриття клапану 8. Циркуляція теплоносія здійснюється за допомогою насосу Н2. Перед насосом встановлений фільтр 4, а також клапан регулювання швидкості теплоносія 5 у внутрішньому контурі (II). Для запобігання високого тиску в контурі встановлений мембранний розширювач 7.

Внутрішній контур (II) являє собою змієвик 6, що прокладений в підлозі та насос Н3, що забезпечує циркуляцію теплоносія в ньому.

Контур ТН (III), тобто сам тепловий насос, включає в себе компресор 3, дросельний клапан 2 , випарник 9 та конденсатор 10.

В зовнішньому контурі (IV) також наявний насос H1, що забезпечує циркуляцію низькотемпературного теплоносія. До нього також встановлений фільтр 1.

Структурна схема описаної вище каскадної САР наведено на рисунку 2.

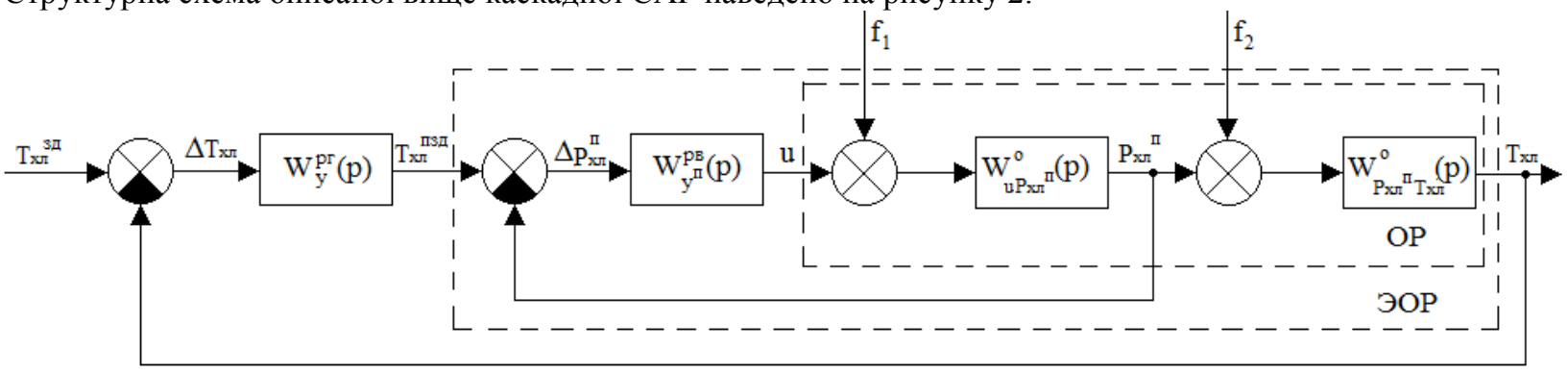

Рис. 2 - Структурна схема каскадної САР за каналом регулювання температури перегріву холодоагенту у випарнику ТН шляхом зміни положення дросельного клапану

За рахунок підвищення динамічної точності регулювання температури перегріву холодоагенту шляхом додаткового виміру тиску холодоагенту у випарнику ТН як проміжної точки, також була підвищена динамічна точність регулювання температури теплоносія теплої підлоги. Порівняльний аналіз перехідних характеристик в традиційній САР з ПІД-регулятором та каскадної САР за значенням критеріїв оптимальності і показників, на які встановлено гранично допустимі значення та за різними каналами, зображений на рис. $3,4$.

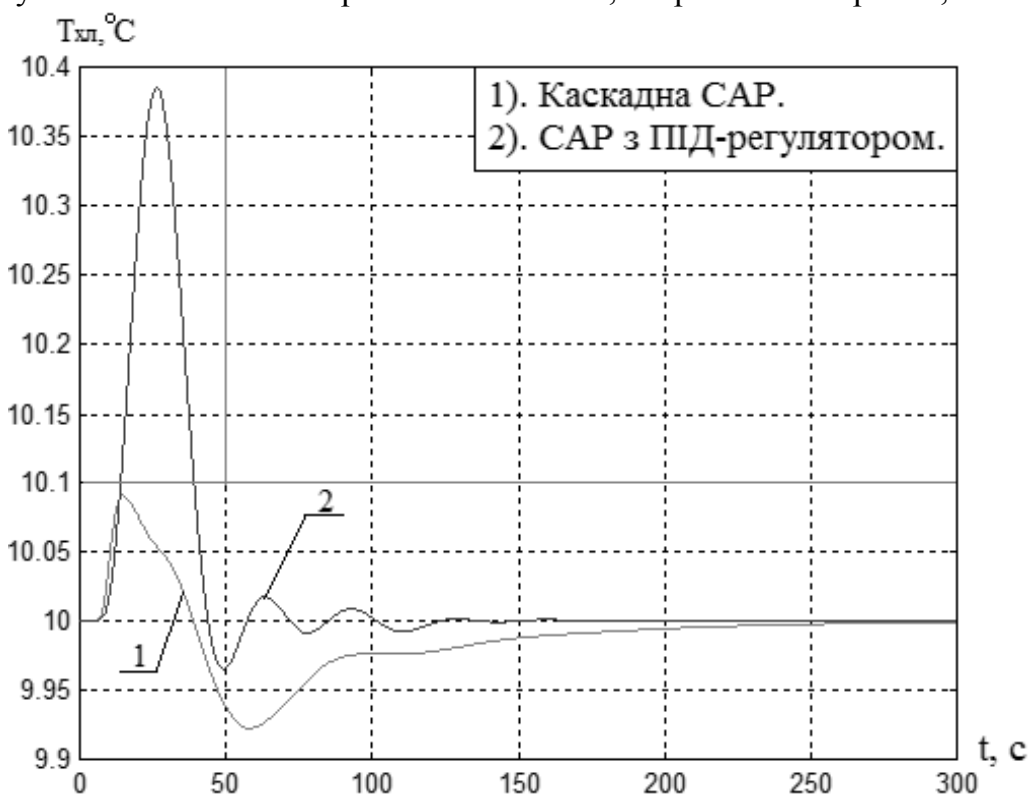

Рис. 3 - Результат порівняння традиційної САР і САР підвищеної динамічної точності за каналом регулювання температури перегріву холодоагенту у випарнику ТН шляхом зміни положення дросельного клапану 


\section{СТУДЕНТСЬКА НАУКА}

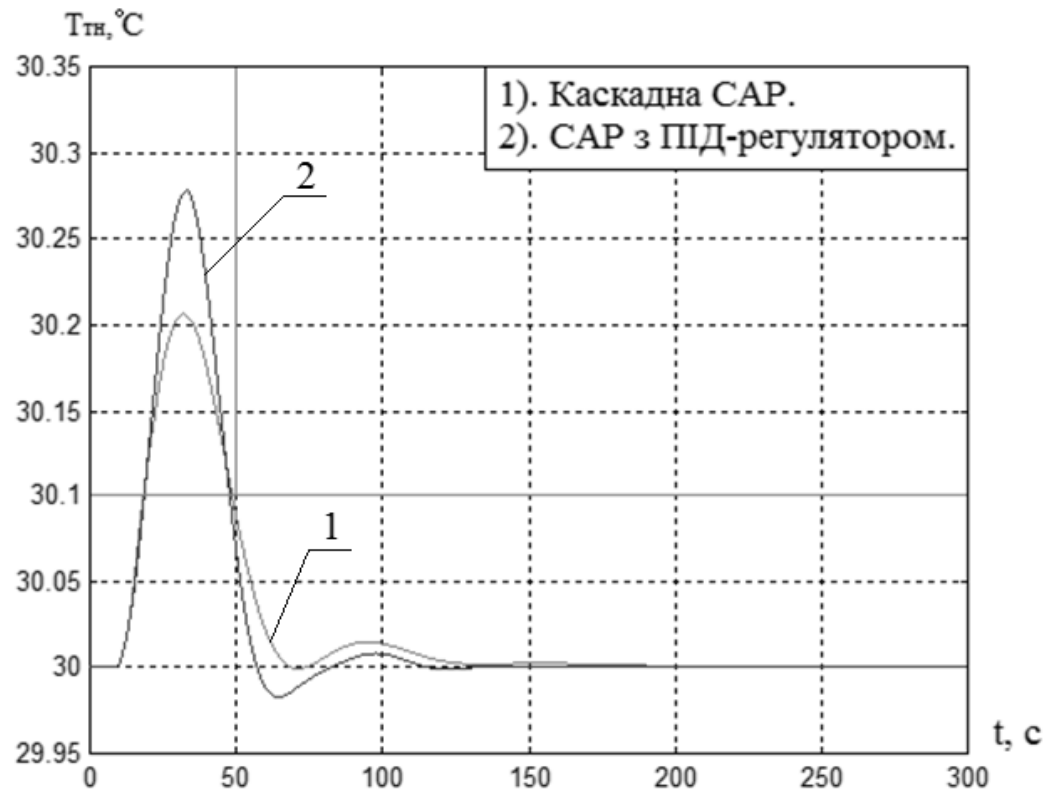

Рис. 4 - Результат порівняння традиційної САР і САР підвищеної динамічної точності за каналом регулювання температури теплоносія теплої підлоги шляхом зміни обертів приводу компресора ТН

На даних результатах чітко просліджується різке зменшення максимального динамічного відхилення та коливальності перехідного процесу в обох каналах. Розглянутий спосіб було реалізовано в SCADA-системі для процесу обігрівання підлоги з використанням ТН (Рис. 5) як АРМ оператора-технолога, який включає графічний інтерфейс із зображенням системи обігрівання та усіма можливими йому функціями для управління цим процесом: налаштування параметрів регуляторів, встановлення температурних режимів, ручне управління керуючими пристроями. Також були передбачені можливості відображення повідомлень щодо режиму та стану роботи системи, графіків перехідних процесів, вікна допомоги, що містить усі тлумачення кожного елементу SCADAсистеми та ін.

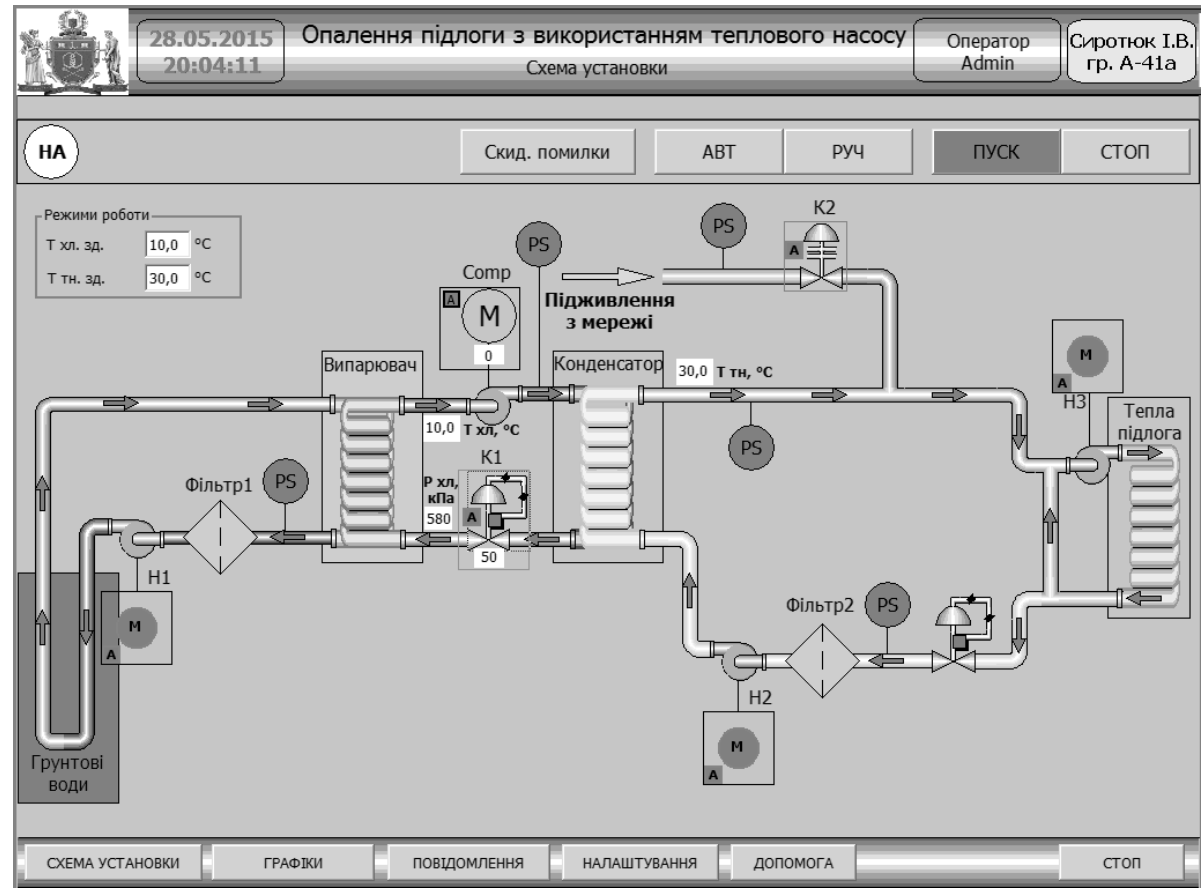

Рис. 5 - Загальний вигляд екрану «Схема установки» АРМ оператора-технолога при нормальній роботі 


\section{Висновок}

Була розроблена система опалення підлоги з використанням ТН, що включає в себе вимірювання та стабілізацію температури теплоносія теплої підлоги та температури перегріву холодоагенту на вході компресора ТН. Внаслідок додаткового виміру тиску у випарнику ТН, була побудована каскадна САР температури перегріву холодоагенту у випарнику ТН. Результати порівняльного аналізу свідчать про підвищення динамічної точності регулювання температури перегріву холодоагенту. Також за рахунок цього була підвищена динамічна точність регулювання температури теплоносія теплої підлоги. Була розроблена SCADA-система для оператора-технолога, яка дає змогу управління системою та слідкування за їі станом безпосередньо з операторського пункту, забезпечує обмежений доступ до управління системою, а також реєструє усі події, аварії та причини їх виникнення, що сталися під час роботи системи.

\section{Література}

[1] Экопродукты, экодома, энергосбережение, охрана окружающей среды. [Електронний ресурс] - Режим доступу: http://realproducts.ru/princyp-raboty-teplovogo-nasosa-sxema-teplovogo-nasosa/. - Мова Рос;

[2] Методические указания к выполнению и оформлению курсовой работы по дисциплине ТАУ «Теория автоматического управления» для студентов специальностей 7.092501 дневной и заочной форм образования / Автор: В.А. Хобин - Одесса: ОНАПТ, 2000;

[3] User's Manual.WinCC flexible 2008 Compact / Standard / Advanced.

References

[1] Ecoproducty, ecodoma, energosberezhenie, ohrana okruzhayushchey sredy.[Electronnyj resurs] - Regym dostupu: http://realproducts.ru/princyp-raboty-teplovogo-nasosa-sxema-teplovogo-nasosa/. - Mova Ros;

[2] Metodicheskie ukazaniya k vypolneniyu i oformleniyu kursovoy raboty po discipline TAU "Teoriya avtomaticheskogo upravleniya" dlya studentov special'nostey 7.092501 dnevnoy i zaochnoy form obrazovaniya / Avtor: V.A. Khobin - Odessa: ONAPT, 2000;

[3] User's Manual.WinCC flexible 2008 Compact / Standard / Advanced.

„Иди прочь, человеческое дитя, к морям и лесам. Пусть фея ведёт тебя за руку

В мире полном слёз и тогда ты узнаешь истину” 